DOI https://doi.org/10.18551/rjoas.2017-03.18

\title{
ANALYSIS OF PROFIT EFFICIENCY AMONG RICE PROCESSORS IN EKITI AND EBONYI STATES, NIGERIA
}

\author{
Obisesan O.O., Salmann K.K. \\ Department of Agricultural Economics, University of Ibadan, Ibadan, Nigeria
}

\author{
Akintayo 0.* \\ Institute of Agricultural Research and Training, Ibadan, Nigeria \\ *E-mail: oluremijayakint@gmail.com
}

\begin{abstract}
The decision by a firm manager to produce or not must be properly harnessed in order to bring about profitability, efficiency and re-investment. Profit efficiency examines the profitability of a firm in relation to other firms in the same industry. This study examines the profit efficiency of rice processors in Ekiti and Ebonyi states in Nigeria. With the use of multistage random sampling technique, a total of 200 rice processors were sampled for the study. Two Local Government Areas (LGAs) from each state were randomly selected. Twenty-five processors were selected from each of four processing sites/centres per LGA. The study utilized the Data Envelopment Analysis (DEA) to estimate the profit efficiency of processors in the study area. The result showed that Ekiti state processors had a profit efficiency of 88 percent, while those in Ebonyi state had 79 percent. In Ekiti state, processors were least profit efficient in transportation (14\%), hiring of operating space $(10 \%)$ and payment for duties and taxes $(28 \%)$. In Ebonyi state, processors were least profit efficient in communication $(13 \%)$, rice paddy $(21 \%)$, maintenance and repairs $(21 \%)$, transportation $(28 \%)$ and fuel $(35 \%)$. It is recommended that more attention be paid to input supply and subsidy to alleviate the cost incurred and thus attract maximum profit. Provision of good motor-able roads to paddy-source and processing centres will also contribute to the reduction of transportation cost.
\end{abstract}

\section{KEY WORDS}

Data Envelopment Analysis (DEA), profit-efficiency, Nigeria.

Rice, a staple of importance in Nigeria, provides food and income to a large number of individuals and rice farming households (Tiamiyu et al., 2012). The crop grows in the six geopolitical zones of the country, under different production systems but does not meet the demand of the growing Nigerian populace. Rice processing is an important aspect of rice production as it represents the stage of value addition to rice cultivated (Ayanwale, 2012). Efforts are constantly being made by the government to increase domestic production and supply of this important staple in order to attain self-sufficiency. However, processing has been identified to be a major bottleneck in attaining this nation goal. The national rice processing capacity has been estimated to be very low. As a result of inadequate modern processing facilities, rice processors employ local methods (usually obsolete and of low capacity) for the processing of their paddy. These rice processors are thus faced with diverse challenges such as low product quality, consumers' acceptability, quality assurance, grades and standardization, product labelling and packaging issues. Faced with such numerous challenges, it becomes crucial for these rice processors to be efficient in the allocation of their resources and making of profit in order to remain in business.

Decisions in economic theory are presented as optimization and minimization problems or as utility or satisfaction maximization (Olayide and Heady, 2006). Therefore, firms are constantly found subjected to the decision of allocating resources, optimizing outputs, optimizing profits and minimizing costs in the best possible way. The decision to produce or not to produce, if and when properly harnessed and managed by decision makers usually 
leads to profitability, profit-efficiency and re-investment. Profit efficiency examines the profitability of a firm as compared to others, while the firm's cost efficiency examines how close a firm is to the best performer's cost (Afza and Asghar, 2012).

Many studies have investigated efficiency with the use of the parametric tools such as the Stochastic Frontier Approach (SFA), Distribution Free Approach (DFA) and Thick Frontier Approach (TFA) and the nonparametric approach which involves the use of Data Envelopment Analysis (DEA) and Free Disposal (FDH). SFA is one of the popular techniques for measuring the level of efficiency which was independently formulated by Aigner et al., (1977), Battese and Corra, (1977) and Meeusen and Van den Broeck, (1977). DEA is a nonparametric method for efficiency evaluation which has been widely applied in agricultural studies. One of the main properties and advantage of DEA is that it does not require any assumptions about the functional form. Copper et al (2006) and Copper et al (2011) have demonstrated that there is no need for the fitting of a functional form in DEA while information on input and output slacks and returns to scale can be determined.

With DEA, the efficiency of a Decision Making Unit (DMU) is simply measured relative to other DMUs with a simple restriction that all DMUs lie on or below an efficient frontier. Thus, DEA constructs a piecewise linear convex frontier connecting the set of best practice observations and envelopes input and output data relative to which costs are minimized or profit/revenue is maximized. Thus, firms' efficiency scores are calculated from the frontiers generated by a sequence of linear programs (Irsova and Havranek, 2007). Application of DEA in agricultural studies include Atici and Podinovski (2015) who analyzed the efficiency of agricultural farms in eight regions of Turkey; Watkins et al (2014) estimated the technical, allocative, economic and scale efficiencies for rice fields enrolled in the verification program in Arkansas, USA.

The main objective of this study was to determine the profit efficiency of rice processors and identify the specific factors which explain variations in efficiency among these processors in Ekiti and Ebonyi states of Nigeria.

\section{METHODS OF RESEARCH}

The Study Area. The study was carried out in Ekiti and Ebonyi states found in the South-Western and South-Eastern zones of Nigeria respectively. Ekiti state which is land locked, is made up of sixteen Local Government Areas (LGAs). The main occupation of dwellers in the state is agriculture, producing food crops like rice, maize, cassava and vegetables. Cash crops such as cocoa, kola nut and oil-palm are also produced. Ebonyi state on the other hand is a semi-savannah land area, made up of 13 LGAs and lies on latitude $5^{\circ} 40 \mathrm{~N}$ and $6^{\circ} 45^{\circ} \mathrm{N}$ and longitude $7^{\circ} 30^{\circ} \mathrm{E}$ and $8^{\circ} 46^{\circ} \mathrm{E}$. The climate is tropical humid characterized by high temperature and sunshine favourable for farming. Major crops grown are rice, cassava, vegetables and oil-palm.

Sampling Technique. Through the use of multi-stage sampling technique, rice processors from the two states were selected. The first stage was the purposive selection of the two states based on their contribution to rice production and processing in Nigeria. The second was the sub-division of the states into urban and rural LGAs. The third stage was the selection of four rice processing centres/localities (two from each of the LGAs, that is, rural and urban). The fourth stage was the selection of twenty five processors from each of the four processing localities or centres, to give a total of 200 respondents.

Analytical Technique. Following Charnes et al (1978), Banker et al (1984) and Banaeian et al (2011), we can have input oriented and output oriented DEA models. However, for this study, the following input oriented DEA is used.

For the input oriented DEA, we have:

$$
\begin{aligned}
& \max z=u y_{j}-\left(u_{j}\right)^{*} \\
& \text { s.t. } v x_{j}=1
\end{aligned}
$$


$-v X+u Y-\left(u_{j} e\right)^{*} \leq 0$

$v \geq 0, u \geq 0,\left(u_{j}\right.$ is free in sign) and the dual is $\min \theta$

s.t. $\Theta x_{j}-X \lambda \geq 0$

$(e \lambda=1)^{\star}$ for $\lambda \geq 0$.

While for the output Orientation DEA we have:

$$
\begin{aligned}
& \min z=v x_{j}-\left(v_{j}\right)^{*} \\
& \text { s.t. } u y_{j}=1 \\
& v X-u Y-\left(v_{j} e\right)^{*} \geq 0 \\
& u \geq 0, u \geq 0,\left(v_{j} \text { is free in sign }\right)
\end{aligned}
$$$$
\text { however the dual is } \max n
$$

s.t. $x_{j}-X \lambda \geq 0$

$n y_{i}-Y \lambda \leq 0$

$(\mathrm{e} \lambda=1)^{*}$ for $\lambda \geq 0$.

Variables for input orientation DEA:

$Y=$ Amount of money obtained from Processing ( $\$$ );

$\mathrm{X}_{1}=$ Amount of money spent on fuel ( $\left.\#\right)$;

$\mathrm{X}_{2}=$ price of paddy ( $\$$ /tonnes);

$X_{3}=$ Amount spent on communication services ( $\$$ );

$X_{4}=$ Amount of money spent on transportation to paddy source $(\$ / K m)$;

$\mathrm{X}_{5=}$ Amount of money spent on transportation from processing unit to point of sale $(\mathbb{A} / \mathrm{Km})$;

$X_{6}=$ Wages for hired labour ( $\$ /$ man hour);

$X_{7}=$ Amount of money paid to family labour (equivalent in cash) ( $\$$ );

$\mathrm{X}_{8}=$ Interest paid on loan ( $\#$;

$X_{9}=$ Cost of maintenance and repairs ( $)$;

$X_{10}=$ Duties and taxes ( $\$$;

$\mathrm{X}_{11}=$ Depreciation on processing unit (\#);

$\mathrm{X}_{12}=$ Rent for operating space ( $\$$ square meter).

\section{RESULTS AND DISCUSSION}

The Socio-economic characteristics of rice processors. The socio-economic characteristics of respondents which include age, marital status, educational level and experience in rice processing were examined using the descriptive statistics such as frequencies and percentages (Table 1).

Male respondents in Ekiti state who were involved in rice processing were 68.90 percent while females were 31.11 percent. This implies that more males were involved in rice processing in this state than females. On the other hand, male respondents involved in Ebonyi were 41.49 percent while the females were 58.51 percent. In Ekiti state, 22.22 percent of the respondents were between 20-40 years and 73.33 percent were between 4160 years of age. In Ebonyi state, 23.06 percent were within the 20-40 age range while 70.97 percent were within the 41-60 age range. Ekiti state processors had the highest as regards secondary education (52.81) percent, while Ebonyi had 37.78 percent. Respondents in Ekiti state with primary school education were 30.34 percent and 16.67 percent in Ebonyi state. However, those with tertiary education involved in rice processing were 13.33 percent higher than those in Ekiti state (5.52) percent. Rice processors in Ekiti and Ebonyi states can be referred to as experienced processors based on the number of years already spent in the business. More than forty percent (46.32\%) of processors in Ekiti state have between 6-10 years of rice processing experience. Furthermore 47.62 percent were found having 11-15 years experience in Ekiti, while 54.05 percent had more than fifteen years experience. 
However in Ebonyi state, processors with 6-10 years processing experience were 42.11 percent while those with more than fifteen years experience were 23.30 percent.

Table 1 - Distribution of respondents by socio-demographic characteristics

\begin{tabular}{|c|c|c|c|c|}
\hline Variables & $\begin{array}{l}\text { Ekiti } \\
\text { Frequency }\end{array}$ & $\begin{array}{l}\text { Ekiti } \\
\%\end{array}$ & $\begin{array}{l}\text { Ebonyi } \\
\text { Frequency }\end{array}$ & $\begin{array}{l}\text { Ebonyi } \\
\%\end{array}$ \\
\hline \multicolumn{5}{|l|}{$\overline{\text { Sex }}$} \\
\hline Male & 62 & 68.90 & 39 & 41.49 \\
\hline Female & 28 & 31.11 & 55 & 58.51 \\
\hline \multicolumn{5}{|l|}{ Age } \\
\hline $0-20$ & - & - & - & - \\
\hline $20-40$ & 20 & 22.22 & 22 & 23.06 \\
\hline $41-60$ & 66 & 73.33 & 66 & 70.97 \\
\hline $61-80$ & 4 & 4.44 & 4 & 4.31 \\
\hline$>80$ & - & - & 1 & 1.08 \\
\hline \multicolumn{5}{|l|}{ Marital Status } \\
\hline Single & 1 & 1.11 & 3 & 3.33 \\
\hline Married & 85 & 94.44 & 95 & 95.74 \\
\hline Divorced/Separated & 1 & 1.11 & - & - \\
\hline Widowed & 3 & 3.33 & 1 & 1.06 \\
\hline \multicolumn{5}{|l|}{ Household size } \\
\hline $1-5$ & 33 & 36.67 & 43 & 49.43 \\
\hline $6-10$ & 55 & 61.11 & 42 & 48.28 \\
\hline$>10$ & 2 & 2.22 & 2 & 2.30 \\
\hline \multicolumn{5}{|l|}{ Educational Level } \\
\hline No Formal Education & 7 & 7.87 & 29 & 32.22 \\
\hline Primary Education & 27 & 30.34 & 15 & 16.67 \\
\hline Quaranic Education & 3 & 3.37 & - & - \\
\hline Secondary Education & 47 & 52.81 & 34 & 37.78 \\
\hline Tertiary Education & 5 & 5.62 & 12 & 13.33 \\
\hline \multicolumn{5}{|l|}{ Years of Experience } \\
\hline $0-5$ & - & - & 2 & 2.70 \\
\hline $6-10$ & 40 & 46.32 & 42 & 42.11 \\
\hline $11-15$ & 30 & 47.62 & 20 & 21.76 \\
\hline $16-20$ & 20 & 54.05 & 10 & 10.65 \\
\hline $21-25$ & 8 & 8.65 & - & - \\
\hline $26-30$ & 2 & 9.70 & - & - \\
\hline$>30$ & $\overline{4}$ & 6.32 & 21 & 22.70 \\
\hline
\end{tabular}

Source: Field Survey, 2016.

The Analysis of Profit Efficiency among Rice Processors. Following Mansoury and Salehi (2011), the profit efficiency of rice processors in the study area was determined alongside the technical and allocative efficiencies. Therefore, the profit efficiency, technical efficiency and allocative efficiency results for rice processors in Ekiti and Ebonyi states are given in Tables 2 and 3 respectively.

Profit efficiency results show that the highest profit efficiency for processors in Ekiti state was 0.88 while that of Ebonyi was 0.79 confirming the outcome of the resource efficiency use of rice farmers by Ogisi et al (2012). This implies that processors were profit inefficient by 12.0 and 21.0 percent respectively. Likewise in milling, for processors making use of pure modern milling techniques, the major source of fuel was diesel, which implies that processors have gotten an alternative to the use of diesel which is the reason why there is a record of high profit efficiencies in fuel usage in the two states. Another reason could be due to the years of experience of processors in processing, majority of the processors could have devised ways of reducing the use of fuel and cost incurred on fuel. Processors were least profit efficient with transportation $(0.14)$, with the hiring of operating space $(0,10)$ and payment for duties and taxes $(0.28)$ in Ekiti state, while in Ebonyi state, processors were least 
profit efficient with communication(0.13), paddy(0.21), maintenance and repairs $(0.21)$, transportation(0.28), fuel(0.35) for Ebonyi state.

Table 2 - Input and Out mix of Rice processors in Ekiti state

\begin{tabular}{lllll}
\hline Parameters & $\begin{array}{l}\text { Input } \\
\text { Cost } \\
\text { (MFC) }\end{array}$ & $\begin{array}{l}\text { Technical Efficiency } \\
\text { Scores (TE) }\end{array}$ & $\begin{array}{l}\text { Profit } \\
\text { Efficiency=TE*AE }\end{array}$ & $\begin{array}{l}\text { Percent AE } \\
\text { Scores }\end{array}$ \\
\hline Fuel & 208,730 & 83 & 0.88 & 0.88 \\
Paddy & 222,000 & 4 & 0.04 & 0.83 \\
Communication service & 12500 & 1 & 0.01 & 0.47 \\
Transportation & 132600 & 2 & 0.02 & 0.14 \\
Labour & 55,500 & 2 & 0.02 & 0.33 \\
Interest on loan & 26,284 & 2 & 0.02 & 0.70 \\
Maintenance and repairs & 130000 & & 14.17 & 0.14 \\
Duties and taxes & 65,500 & & 28.14 & 0.28 \\
Operating space & 182,100 & & 10.12 & 0.10 \\
Others & 168,700 & & 10.93 & 0.11 \\
\hline
\end{tabular}

Source: Field Survey, 2016.

Table 3 - Input and Out mix of Rice processors in Ebonyi state

\begin{tabular}{lllll}
\hline Parameters & $\begin{array}{l}\text { Input } \\
\text { Cost (\#) } \\
\text { MFC }\end{array}$ & $\begin{array}{l}\text { Technical Efficiency } \\
\text { Scores (TE) }\end{array}$ & $\begin{array}{l}\text { Profit Efficiency= TE } \\
{ }^{*} \text { AE }\end{array}$ & $\begin{array}{l}\text { Percent Profit } \\
\text { Efficiency } \\
\text { Scores }\end{array}$ \\
\hline Fuel & 179,700 & 36 & 35.07 & 0.35 \\
Paddy & 296650 & 13 & 21.25 & 0.21 \\
Communication service & 55,500 & 11 & 113.56 & 0.13 \\
Transportation & 225,300 & 6 & 27.98 & 0.28 \\
Labour & 79600 & 5 & 79.18 & 0.79 \\
Interest on loan & 121,246 & 19 & 51.98 & 0.51 \\
Maintenance and repairs & 294,500 & & 21.39 & 0.21 \\
Operating space & 102,300 & & 61.61 & 0.62 \\
Others & 102,000 & & 61.79 & 0.62 \\
\hline
\end{tabular}

Source: Field Survey, 2016.

\section{CONCLUSION}

The profit efficiency of rice processors in the study area was not determined in isolation as it was estimated alongside the technical and allocative efficiencies focusing on two rice processing states in the south-western and south-eastern states of Nigeria. Processors in the study area were found to have high profit efficiency. The result also shows that the highest profit efficiency for processors in Ekiti state was 0.88 while that of Ebonyi state was 0.79 . The socio-economic characteristics of respondents which include: age, sex, marital status; educational level and experience in rice processing were examined. The study showed that more males were involved in rice processing in Ekiti state than females. In Ebonyi state, more female respondents were involved in rice processing than males. The middle aged adults were represented more (41-60 years) in rice processing in both states, than the youths and older people. More respondents had secondary school education than the other forms of education represented in the study. Processors in the study area are well experienced in rice processing based on the number of years already spent in the business.

It is therefore recommended that more attention should be paid to input supply and input subsidies by all stake-holders involved in the rice-subsector in order to alleviate the cost incurred during rice processing there-by attracting maximum profit. These increased profits will cover up for the cost of maintenance and repairs, communication and fuel usage. Provision of good motor-able roads by the government to paddy-source and processing centres will also drastically reduce the cost of transportation. 


\section{REFERENCES}

1. Aigner, D.; Lovell, C. A. K.; Schmidt, P.(1977). Formulation and estimation of stochastic frontier production function mod $\urcorner$ els. Journal of Econometrics 6:21-37

2. Afza, T and Asghar, J.A. (2012). Financial reforms and efficiency in the insurance companies of Pakistan. African journal of Business Management 6(30):8957-8963

3. Atici, K. B., and Podinovski, V. V. (2015). Using data envelopment analysis for the assessmentof technical efficiency of units with different specialisations: An application to agriculture. Omega 54:72-83

4. Ayanwale (2012). Demand Supply Response and Preference Switch for Rice in Nigeria. Unpublished PhD Thesis of the Department of Agricultural Economics, University of Ibadan, Oyo State, Nigeria.

5. Banaeian, N., Omid, M and A. Hojat (2011). Application of Data Envelopment Analysis to Evaluate Efficiecncy of Commercial Greenhouse Starwberry. Research Journal of Applied Science, Engineering and Technology 3(3):185-193

6. Banker, R.D., A Chanes and W.W. Cooper (1984). Some Models for Estimating Technical and Scale Inefficiencies in Data Envelopment Analysis. Management Science 30(9): 1078-1092.

7. Battese, G. E. and Corra, G. S. (1977). Estimation of a production frontier model: With application to the Pastoral zone of Eastern Australia. Australian Journal of Agricultural Economics Vol. 21(3)

8. Burja, C. and Burja, V. (2016) Farm size and efficiency of the production factors in Romanian agriculture. Economics of Agriculture 2/16 UDC 631.11/151(498). Accessed on 13/3/2017 from www.ea.bg.ac.rs/images/Arhiva/2016/

9. Coelli, T. (1995). Recent Developments in Frontier Estimation and Efficiency Measurement. Australian Journal of Agricultural Economics 39: 219-45.

10. Charnes A., Cooper W.W., and Rhodes, E. (1978). Measuring the efficiency of decision making units. European Journal of Operational Research 2(6):429-444.

11. Cooper, W., Seiford, L.M. and Tone, K. (2006). Introduction to Data Envelopment Analysis and its Use. 233 Spring Street, New York, NY 10013, USA: Springer Science \& Business Media Inc.

12. Copper, W., Seiford, L. M. and Zhu, J. (2011). Data Envelopment Analysis: History, models and interpretation. Accessed on 26th March, 2016 from https://www.researchgate.net/publication/226038831.

13. Mansoury, A. and Salehi, M (2011). Efficiency analysis and classification of bank by using data envelopment analysis (DEA) Model: Evidence of Iranian Bank. International Journal of Physical Sciences Vol.6(13):3205-3217

14. Meeusen, W. and Van den Broeck, J (1997). Efficiency Estimation from Cobb-Douglas Production Functions with Composed Error. International Economic Review 18, 435444.

15. Ogisi, O D., Chukuwuji, C. O. and Okeke D. C. (2012). Efficiency of Resource Use by Rice Farmers in Ebonyi State, South East Nigeria: A Data Envelopment Analysis. Asian Economic and Social Society Volume 2 No.2 June 2012.

16. Olayide, S.O and Heady, E.O (2006). Introduction to Production Economics. Ibadan University Press, Ibadan, Nigeria.

17. Tiamiyu S.A., Usman, A, and Ugalahi, U.B (2014). Adopting of On-farm and Postharvest Rice Quality Enhancing Technologies in Nigeria. TROPICULTURA 32(2):67-72.

18. Irsova, $Z$ and Havranek, T. (2007). Measuring Bank efficiency: A meta-regression analysis. DOI:10.18267/j.pep.379.

19. Watkins, H.B., Hristovska, T., Mazzanti, R., Wilson, C.E. Jnr., and Schmidt, L. (2014) Measurement of technical, allocative, economic and scale efficiency of rice production in Arkansas using data envelopment analysis. Journal of Agricultural and Applied Economics 46(1):89-106 